Ekonomia - Wroclaw Economic Review 23/2 (2017)

Acta Universitatis Wratislaviensis

No 3770

DOI: $10.19195 / 2084-4093.23 .2 .2$

Walter E. Block, Ph.D.

Harold E. Wirth Eminent Scholar Endowed Chair and Professor of Economics Joseph A. Butt S.J. College of Business Loyola University New Orleans

wblock@loyno.edu

\title{
Rejoinder to Guenzl on Theft and the Return of Private Property
}

Date of submission: 5th of October 2016; date of acceptance: 29th of January 2017

JEL Classification: H0, F2

Keywords: property, aggression, theft, libertarianism

Abstract

Rejoinder to Guenzl on Theft and the Return of Private Property

Suppose A is the rightful owner of some property, B steals if from him, and C, in turn, relieves B of his ill-gotten gains. What next? Under just law, must $C$ return the item to $A$ ? If not, is $C$ guilty of a crime? If $\mathrm{C}$ does return this resource to its initial (rightful?) owner, does A owe $\mathrm{C}$ a percentage of its value, as under salvage law? These are some of the questions to be wrestled with in the present paper.

\section{Introduction}

Lest I be accused of false advertising in my choice of title of this paper, let me begin with a clarification. Guenzl $(2016)^{1}$ is concerned almost entirely with the immigration debate, one to which I have contributed my fair share. ${ }^{2}$ And, indeed, Guenzl does launch a scathing critique of my work. But, not on immigration, a topic on which he and I largely, no, fully, agree. Instead, in an article mainly concerned with the rights of international travelers, Guenzl yet finds space to criticize my publications on a very different subject, the return of stolen property to its rightful owner. Hence, the divergence between the title of the

1 All references to this author will be to this one paper of his.

2 See Block and Callahan 2003; Gregory and Block 2007. 
present paper, which faithfully depicts Guenzl's challenge to me, and the title of his own paper, which does not at all. ${ }^{3}$

I welcome Guenzl to the libertarian debate on immigration (and justice in the return of stolen property). He offers new insights to the analysis of this complex subject and thereby makes an important contribution to it. However, while I am in full agreement with everything he writes on immigration, I must part company with him on that part of his paper critically directed at my own treatment of the return of stolen property. In section II, I deal with his claim that my publications are not internally consistent with each other. The gist of section III is to comment on Guenzl's section, "No man's land". Section IV deals with several errors made by our author in his otherwise excellent critique of Hoppe on immigration. Section V is my attempt to wrestle with objections he launches at my views on Ragnar Danneskjold, (Rand 1957) and his dealings with robbers. We conclude in section VI.

\section{Inconsistency}

What is Guenzl's claim that I am guilty of logical inconsistency? First, he maintains that in my view, public property is unowned. And, indeed, he is correct in this contention. I most certainly did say what he quotes me as saying (Block 1998, pp. 180-181; Gregory and Block 2007, p. 35) in this regard. Second, he cites me (2011, pp. 605-618) as writing that it is owned. Again, I have no objection to what he attributes to me; his assessment is entirely accurate. How can these seemingly contradictory sets of statements of mine be reconciled? Simple. Sometimes I discuss de jure and at other times, in other contexts, de facto claims; upon some occasions I deliberate upon what is, as a matter of fact, and on yet in others, on what should be. ${ }^{4}$ Never the twain shall meet. Never the twain are even in the same universe of discourse. Therefore, never the twain can possibly contradict one another. My views on these matters, consistent over many years through many, many publications, is that governments do indeed own property such as farms and fields, bridges and cars, ships and sealing wax. They own it in the sense that they can use it as they wish, and can legally prevent others from doing with these properties anything they themselves oppose. ${ }^{5}$ This applies to land untouched by human

${ }^{3}$ If Guenzl were concerned with false advertising, he might have included not only immigration in the title of his own paper, but also the issue on which he criticizes me, namely, return of stolen property. Or, he might have written two separate papers, one on each of these topics.

4 At least in terms of what I consider proper libertarian law.

5 States Malcolm (1958, pp. 31-32) of his teacher and mentor Ludwig Wittgenstein: "On one walk he 'gave' to me each tree that we passed, with the reservation that I was not to cut it down or do anything to it, or prevent the previous owners from doing anything to it: with those reservations it was henceforth mine." 
hands, ${ }^{6}$ acreage seized by the state from rightful owners ${ }^{7}$ and resources purchased by government through voluntary sales to it, but with money mulcted from taxpayers coercively. How much land should the government own? No one single solitary square inch of it; indeed, the entire enterprise is an illicit one based on its initiation of aggression against innocent people. But the state indeed actually owns vast amounts of land and other resources, de facto. And it is the owner of the same amount de jure, based on its own laws. However, it is the proprietor of none at all de jure, from a libertarian point of view. Of course the taxpayer is the rightful owner of these properties that have been stolen from him, as are the homesteading victims of eminent domain, or those who purchased these resources through legitimate means; this is, in contrast, a normative statement. Of course, also, and non-contradictorily, these properties are unowned, in the very different sense that their present actual owner is not entitled to them. And, then, there are untouched areas of the wilderness improperly claimed by the state, but are now unowned, and will only come into ownership when, finally, they are homesteaded.

Is it not true that "... public libraries ... are $a \mathrm{kin}^{8}$ to an unowned good" in the sense that the government, their claimant, does not have proper title to them? Is it not true "that the hapless taxpayers, and those victimized by eminent domain to build them, are instead the de jure owners of the roads, at least from a libertarian perspective"? I cannot see my way clear to viewing these two statements as contradicting one another.

Nothing daunted, Guenzl sees a second set of logical contradictions, courtesy of the present author. He avers "Block's version of the PP ownership theory may be different from the one articulated by Hoppe and Kinsella. Sometimes Block explicitly characterizes public property as having been stolen from taxpayers, whereas at other times he takes the same line as Hoppe and Kinsella, who seem more disposed to say that it is the funds used by the state to finance its claim to public property that have been stolen, and that this income theft somehow leads to the taxpayers being the legitimate owners of such property. In the end, all three agree that the taxpayers are the rightful owners of public property." When offered the choice between vanilla and chocolate ice cream, I invariably reply, "both". I say the same thing now, in the present context. Sometimes public property is stolen by government from the owners, directly. On other occasions, it is purchased with money robbed by them through taxation. Again, I plead not guilty to the charge of logical inconsistency.

6 Or feet. For example, parts of the Rocky Mountains, much of Alaska.

7 For example, through eminent domain or Civil Asset Forfeiture. See on this: Rothschild and Block 2016; Baicker and Jacobson 2007; Chi 2002; Doyle 2008; Moores 2009; Naylor 2000; Pimentel 2012; Rulli 2001; Warchol and Johnson 1996; Williams, Holcomb and Kovandzic 2010, 2011.

8 Does not this one word, "akin", alone, absolve me from any accusation of contradicting myself? 


\section{No man's land}

Our author starts off this section of his paper with the claim that “... neither can the taxpayers be forced to accept state-claimed land as their only restitution. The taxpayers have been deprived of a liquid asset, and it would seem incongruous to claim their only solution is to take possession of an illiquid asset. Imagine if the stolen income had been used to purchase some unusable objects; would we say the taxpayers' only recourse is to take possession of these worthless items?" And of course he is correct in this claim. But no libertarian to my knowledge ever denied this. Yes, libertarian punishment theory ${ }^{9}$ asserts that as a first step, exactly what was stolen from the victim should be returned to him. ${ }^{10}$ If land, then that very specific bit of terrain. If the liquid asset money, then that precise amount of funds. ${ }^{11}$ However, if financial assets were taken, and cannot be returned, and land was purchased with these resources, it seems not unreasonable to compensate the victim with that acreage, certainly in lieu of nothing at all.

\section{Other errors}

I am in general agreement with Guenzl's critique of Hoppe on immigration. Indeed, I have published more than a few statements in support of the libertarian case for open borders. ${ }^{12}$ However, in making his excellent rebuttal, Guenzl enters into several thickets, and I shall attempt to rescue him from them. For example, this author mentions that every member of the East German society contributed at least something to its well-being, such as it was: "It seems manifestly inaccurate to say that the citizen of a socialist state, who is in effect completely enslaved to the state, has 'contributed literally nothing' to the state's seizure and continued occupation of state-claimed land. By what means could the state identify, gain access to, take control of, and maintain and use this property other than through the expropriated labor and/or income of the general citizenry?" But what about a severely mentally handicapped person, maybe even one so physically afflicted?

9 Barnett 1977; Barnett and Hagel 1977; Block, Block, Barnett and Callahan 2005; Gregory and Block 2007; Kinsella 1996; Morris 1968; Nozick 1981, pp. 363-373; Olson 1979; Rothbard 1998, p. 88; Whitehead and Block 2003. In the view of Rothbard (1998, p. 88, ft. 6): "It should be evident that our theory of proportional punishment - that people may be punished by losing their rights to the extent that they have invaded the rights of others - is frankly a retributive theory of punishment, a 'tooth (or two teeth) for a tooth' theory. Retribution is in bad repute among philosophers, who generally dismiss the concept quickly as 'primitive' or 'barbaric' and then race on to a discussion of the two other major theories of punishment: deterrence and rehabilitation. But simply to dismiss a concept as 'barbaric' can hardly suffice; after all, it is possible that in this case, the 'barbarians' hit on a concept that was superior to the more modern creeds."

${ }^{10}$ If at all possible.

11 With due consideration given to payments based on the interest rate.

12 See fn. 2, supra. 
Or consider a bum, a ne'er do well, a drunkard. Were there no such persons in East Germany? Did the government there succeed in creating Communist Man, not subject to any of these characteristics? Of course not. So it would appear that at least some denizens of this country did not contribute, positively, to its wellbeing. One point for Hoppe, not Guenzl.

Next, our author states: "Much of the writing in this debate simply assumes the PP ownership theory without laying out the principles underpinning it. The answer to this question that accords with Rothbardian property rights principles is that neither the state nor the taxpayers, and potentially no one, owns state-claimed land." ${ }^{13}$ But are we talking normative or positive here? It makes a huge difference. It would be a strange situation where literally no one owned, was able to use, "state-claimed" land. No one would have any use for the roads, streets and highways? If so, would not most of the population die in short order? Surely, Guenzl is not asserting that no one has a right to take over property claimed by the state. $\mathrm{He}$ is a staunch libertarian, and we are the victims, after all.

Another awkwardness concerns this offering of his: "The only way I can see of validating the PP ownership theory is through the idea that (some) taxpayers might consent to their income being used to finance the homesteading of stateclaimed land. However, we cannot assume all taxpayers would consent..." This sounds as if, if not quite, Guenzl is applauding citizens who donate money to the government. Perish the thought. If true, and I cannot believe that this is his actual viewpoint, it would run counter to the traditional libertarian perspective of considering such people as criminals. After all, the government is itself an illicit norganization. ${ }^{14}$ Thus, anyone who aids and abets it falls under that rubric too. When the libertarian Nuremberg trials occur, such folk will be in the dock. It is also difficult to credit Guenzl's conclusions from these remarks of his: “... taxpayers do not legitimately own state-claimed land." If the taxpayers ${ }^{15}$ do not, who, pray tell, does? Are these lands to lie fallow forevermore?

13 Footnote omitted. According to Guenzl, “...the legitimate owners of public property are those taxpayers whose income or wealth (hereafter, 'income') was expropriated by the state to fund the state's control of such property (what I will call the 'PP ownership theory')".

${ }^{14}$ In the view of Rothbard (1973, emphasis added by present author) "For centuries, the State (or more strictly, individuals acting in their roles as 'members of the government') has cloaked its criminal activity in high-sounding rhetoric. For centuries the State has committed mass murder and called it 'war'; then ennobled the mass slaughter that 'war' involves. For centuries the State has enslaved people into its armed battalions and called it 'conscription' in the 'national service.' For centuries the State has robbed people at bayonet point and called it 'taxation.' In fact, if you wish to know how libertarians regard the State and any of its acts, simply think of the State as a criminal band, and all of the libertarian attitudes will logically fall into place".

15 Or future homesteaders. 


\section{Ragnar}

We now arrive at Guenzl's main criticism of me. He objects to my use of the fictional character, Ragnar Danneskjold, ${ }^{16}$ brought to us in Rand's (1957) magnificent novel. In this scenario, A is the rightful owner of some property. B, the government, steals it from A. C, our hero, Ragnar, relieves B of his ill-gotten gains. Ideally, and simply, Guenzl and I would both agree, C should then return the resource to A. So far so good. But, suppose Ragnar declines to do so. Is this is a better or worse situation from the libertarian point of view? Clearly, better. For without Ragnar, B would keep what he stole from A and that would be the end of the story. At least, it cannot be denied, this liberator of the good, transferring it from $\mathrm{A}$ to $\mathrm{C}$, makes things far more interesting.

What is Guenzl's "refutation" of my defense of Ragnar keeping A's property? He writes (footnote omitted): “...libertarians recognize only three ways to legitimately come to possess property - namely, homesteading, voluntary transfer, and the exercise of remedial rights. In Block's example, $\mathrm{C}$ has not homesteaded previously unowned property, has not received it from A in a voluntary transfer, and has not been wronged and thus has no remedial rights. Therefore, C's possession is illegitimate. I agree with Block that $\mathrm{C}$ cannot be deemed a thief, but that is not the end of the matter. Rothbard (1982) has argued, convincingly in my view, that a libertarian legal regime would recognize the tort of trespass, which is how I would characterize C's possession of A's property in the present case. According to Rothbard (1982, p. 82), a trespass is a "visible and tangible or "sensible" invasion, which interferes with possession and use of the property.' Hence I believe that the liberator theory is at odds with Rothbardian property rights principles, and, as such, it cannot be a sound basis on which to ground a libertarian 'open borders' argument."

There are problems here. I concocted the Ragnar scenario in order to respond to a very powerful critique of libertarianism. This was the claim that many if not all supporters of this philosophy are hypocrites since a goodly few work for the state, for example, teach at a public university. Or, virtually all of us benefit from its largesse in any number of ways, such as by using its subsidized post office, or traveling on its roads streets and highways, enacting business with its currency, or visiting its libraries and museums; this applies, even, to our eating food, wearing clothes, the raw materials of which are subsidized by the government. Why hypocrisy? It is because all of these things are given to C, the libertarians, by $\mathrm{B}$, the state, and where did that institution get them, or the money to manufacture them? From A, the taxpayer. Of course, libertarians, too are taxpayers, but, still, if they benefit from the government to a greater degree than they pay into it, as

16 Block 2004, 2007, 2011A, 2011B; Block and Arakaky 2008; Block and Barnett 2008; D'Amico and Block 2007. 
would be the case, for example, for a professor at a public university, then they are in effect stealing, on a net basis, from the As who pay more than they receive. ${ }^{17}$ Without a Ragnar who can obviate this criticism, how can libertarians defend themselves? Guenzl vouchsafes us no answer. This is not an utter annihilation of his position, but it leaves it in an awkward, anti-libertarian stance. Can this author assert unambiguously that he does not benefit on a net basis from the government? If not, he, too, must join the rest of us hypocritical libertarians.

Then there is the case of salvage at sea. A's ship capsizes and sinks to the ocean floor. A escapes in a row boat. $\mathrm{C}$ comes along, ${ }^{18}$ rescues this sunken treasure, and brings it to shore. If he keeps it, in Guenzl's view, he is a trespasser. $\mathrm{C}$ must return the ship to A, holus-bolus. But a series of salvage findings by natural law (e.g. libertarian) courts, have decided otherwise: A and C must split the value of the ship, typically roughly two thirds for the former, one third for the latter. ${ }^{19}$ That is to say, if we extrapolate from this example, our Ragnar may retain $33 \%$ of what he liberates from the state; as for the rest, the burden of proof must rest with any A who claims more from Ragnar than that; he must demonstrate that he make his approach with fully clean hands; that is to say, the critic of libertarianism on these grounds, A must prove that he is a net tax payer, not receiver, in Calhounian terms.

Guenzl claims that according to Rothbard there are only three legitimate claims to proper ownership: homesteading, voluntary transfer and remedial rights, and that this should be definitive. One problem with this is that it is he, Guenzl, not Rothbard, who employs the "only". But suppose that the latter buys into this notion. Guenzl's use of such a claim would veer dangerously close to an argument from authority. Rothbard (hypothetically) says this, therefore it is correct? Not so, not so. Perhaps Rothbard in this case overlooked a fourth justification, liberating from a thief. Guenzl's reliance on Rothbard as an authority comes with particular ill-grace since he himself rejects the latter's more mature views on open borders: Guenzl agrees with me, not Rothbard, on this matter (Block 2011A).

Consider one last example. A freedom fighter (C) breaks into a Nazi (B) garage, and is about to torch some of the vehicles parked within. Along comes the rightful owner (A) of one of them, a jeep, and protests C's act, saying that he, A, is the rightful owner of the automobile, and forbids $\mathrm{C}$ from destroying it. Guenzl, if I read him correctly, would support A in this matter. Here, it is not as if A himself can drive out of the garage with his own property. No, no, no, it stays in Nazi hands, there to continue perpetrating evil. My point is that $\mathrm{A}$, in opposing $\mathrm{C}$, is aiding and abetting B. A's position as an innocent bystander, as a rightful owner, is thereby fatally compromised. And, Guenzl's argument, along with him.

17 For this way of looking at the matter, see Calhoun (1953).

18 I am reserving "B" for the bad guy, government.

19 Anderson 1993; Doane 2013; Kinsella 2010; Lipka 1970; Wilder 2000. 


\section{Conclusion}

Despite the foregoing criticisms, I regard Guenzl's contribution as by far a very positive one. His critique of the views of Rothbard, Hoppe and Kinsella on immigration are very welcome, since these three are towering giants of the libertarian movement, and they are very much mistaken on this one issue, immigration.

\section{References}

Anderson, Andrew. 1993. Salvage and Recreational Vessels: Modern Concepts and Misconceptions; http://www.safesea.com/salvage/law/anderson/anderson_main.html; http://www.safesea.com/ salvage/law/anderson/anderson_background.html.

Baicker, Katherine and Mireille Jacobson. 2007. "Finders Keepers: Forfeiture Laws, Policing Incentives, and Local Budgets. Journal of Public Economics, Elsevier B.V., pp. 2113-2136; http:// users.nber.org/ jacobson/BaickerJacobson2007.pdf.

Barnett, Randy E. 1977. "Restitution: A New Paradigm of Criminal Justice", in: Assessing the Criminal: Restitution, Retribution, and the Legal Process, eds. R. Barnett and J. Hagel, Cambridge, Mass.: Ballinger.

Barnett, Randy, and Hagel, John, (eds.) 1977. Assessing the Criminal, Cambridge MA: Ballinger.

Block, Walter E. 2004. "Radical Libertarianism: Applying Libertarian Principles to Dealing with the Unjust Government, Part I" Reason Papers, Vol. 27, Fall, pp. 117-133; http://www.walterblock.com/wp-content/uploads/publications/block_radical-libertarianism-rp.pdf.

Block, Walter E. 2007. "Ron Paul and Matching Funds," October 1; http://archive.lewrockwell.com/ block/block86.html.

Block, Walter E. 2011A. "May a Libertarian Take Money From the Government?” March 11; http:// archive.lewrockwell.com/block/block175.html; https://www.lewrockwell.com/2011/03/walter-e-block/may-a-libertarian-take-money-from-the-government/.

Block, Walter E. 2011B. "Toward a Libertarian Theory of Guilt and Punishment for the Crime of Statism," Journal of Libertarian Studies, Vol. 22; pp. 665-675; http://mises.org/journals/jls/ 22_1/22_1_33.pdf.

Block, Walter E. 2015. “On immigration.” December 21; http://www.economicpolicyjournal. com/2015/12/walter-block-on-immigration.html.

Block, Walter E. and Chris Arakaky. 2008. “Taking Government Money for Grad School?” May 23; http://archive.lewrockwell.com/block/block100.html.

Block, Walter E. and Gene Callahan. 2003. "Is There a Right to Immigration? A Libertarian Perspective," Human Rights Review. Vol. 5, No. 1, October-December, pp. 46-71; http://www. walterblock.com/publications/block-callahan_right-immigrate-2003.pdf.

Block, Walter E. and William Barnett II. 2008. "Continuums" Journal Etica e Politica / Ethics \& Politics, Vol. 1, pp. 151-166 June; http://www2.units.it/ etica/; http://www2.units.it/ etica/2008_1/ BLOCKBARNETT.pdf.

Calhoun, John C. 1953. A Disquisition on Government, New York: Liberal Arts Press.

Chi, Karis Ann-Yu. 2002. "Follow the Money: Getting to the Root of the Problem with Civil Asset Forfeiture in California." California Law Review, Oct., Vol. 90, No. 5, pp. 1635-1673.

D'Amico, Dan and Walter E. Block. 2007. "A Legal and Economic Analysis of Graffiti” Humanomics, Vol. 23, No. 1, pp. 29-38; http://www.mises.org/journals/scholar/damico.pdf; http://www. emeraldinsight.com/Insight/viewContainer.do? containerType=Issue\&containerId=24713; http://ssrn.com/abstract=1008525. 
Doane, Charles. 2013. “SALVAGE LAW: Do You Get to Keep an Abandoned Boat?” July 15; http:// www.sailfeed.com/2013/07/salvage-law-do-you-get-to-keep-an-abandoned-boat/.

Doyle, Charles. 2008. Crime and Forfeiture. Nova Science Publishers, pp. 1-89; http://digital.library.unt.edu/ark:/67531/metadc282308/m1/1/high_res_d/97-139_2013May13.pdf.

Gregory, Anthony and Walter E. Block. 2007. "On Immigration: Reply to Hoppe." Journal of Libertarian Studies, vol. 21, No. 3, Fall, pp. 25-42; http://mises.org/journals/jls/21_3/21_3_2.pdf; http://www.academia.edu/1360109/On_Immigration_Reply_to_Hoppe.

Guenzl, Simon. 2016. "Public Property and the Libertarian Immigration Debate." Libertarian Papers. 8 (1): 153-177. libertarianpapers.org; http://141.164.71.80/exchange/walterblock/Inbox/ RE:\%20November\%202\%20Talk\%20at\%20Yale.EML/1 multipart xF8FF 2 lp-8-1-7-2. pdf/C58EA28C-18C0-4a97-9AF2-036E93DDAFB3/lp-8-1-7-2.pdf?attach=1.

Kinsella, Stephen. 1996. "Punishment and Proportionality: the Estoppel Approach", The Journal of Libertarian Studies, Vol. 12, No. 1, Spring, pp. 51-74; http://www.mises.org/journals/jls/12_1/ 12_1_3.pdf.

Kinsella, Stephan. 2010. "Legislation and Law in a Free Society." February 25; http://mises.org/ daily/4147.

Lipka, Lawrence J. 1970. “Abandoned Property at Sea: Who Owns the Salvage 'Finds'?”, William \& Mary Law Review, Vol. 12, No. 1, http://scholarship.law.wm.edu/cgi/viewcontent.cgi?article $=2713 \&$ context $=$ wmlr.

Malcolm, Norman. 1958. Ludwig Wittgenstein: A Memoir. Oxford: Oxford University Press.

Moores, Eric. 2009. "Reforming the Civil Asset Forfeiture Reform Act". Arizona Law Review, Vol. 51, pp. 777-803; http://www.arizonalawreview.org/pdf/51-3/51 arizlrev777.pdf.

Morris, Herbert. 1968. "Persons and Punishment”, The Monist, Vol. 52, Issue 4: October, pp. 475-501; http://www.law-lib.utoronto.ca/bclc/crimweb/bboard/personsandpunishment.pdf.

Naylor, R.T. 2000. "Wash-out: A Critique of Follow-The-Money Methods in Crime Control Policy." Crime, Law \& Social Change, Netherlands: Kluwer Academic Publishers, pp. 1-57.

Nozick, Robert. 1981. Philosophical Explanations, Cambridge, MA: Harvard University Press.

Olson, Charles B. 1979. "Law in Anarchy", Libertarian Forum, Vol. XII, No. 6, November-December, p. 4; http://64.233.167.104/u/Mises?q=cache:gFT18_ZusWoJ:www.mises.org/journals/ 1f/1979/1979_11-12.pdf+two+teeth+for+a+tooth\&hl=en\&ie=UTF-8.

Pimentel, David. 2012. "Forfeitures Revisited: Bringing Principle to Practice in Federal Court". Nevada Law Journal 13.1, pp. 3-59.

Rand, Ayn. 1957. Atlas Shrugged, New York: Random House.

Rothbard, Murray N. 1973. For a New Liberty, Macmillan, New York; http://www.mises.org/rothbard/newliberty.asp.

Rothbard, Murray N. 1998. The Ethics of Liberty, New York: New York University Press. http:// www.mises.org/rothbard/ethics/ethics.asp.

Rothschild, Daniel Y. and Block, Walter E. 2016. "Don't Steal; The Government Hates Competition: The Problem with Civil Asset Forfeiture", The Journal of Private Enterprise, 31(1), pp. 45-56; http://journal.apee.org/index.php/2016_Journal_of_Private_Enterprise_vol_31_no_1_parte4.pdf.

Rulli, Louis S. 2001. "The Long Term Impact of CAFRA: Expanding Access to Counsel and Encouraging Greater Use of Criminal Forfeiture", Federal Sentencing Reporter, September/October, Vol. 14, No. 2, Forfeiture: Recent Reform and Future Outlook, University of California Press: Vera Institute of Justice, pp. 87-97.

Warchol, Greg L., and Brian R. Johnson. 1996. "Guilty Property: A Quantitative Analysis of Civil Asset Forfeiture", American Journal of Criminal Justice 21.1, pp. 61-81.

Whitehead, Roy and Walter E. Block. 2003. "Taking the assets of the criminal to compensate victims of violence: a legal and philosophical approach", Wayne State University Law School Journal of Law in Society, Vol. 5, No. 1, Fall, pp. 229-254.

Ekonomia - Wroclaw Economic Review 23/2 (2017)

(C) for this edition by CNS 
Wilder, Mark A. 2000. "Application of Salvage Law and the Law of Finds to Sunken Shipwreck Discoveries", Defense Counsel Journal, January; http://www.rms-republic.com/reference/ Volume67No1Article6.pdf.

Williams, Marian R., Jefferson E. Holcomb, and Tomislav V. Kovandzic. 2011. "Civil Asset Forfeiture, Equitable Sharing, and Policing for Profit in the United States", Journal of Criminal Justice, pp. 273-285; http://walker-foundation.org/files/walker/2011/afjournalofcriminaljustice.pdf.

Williams, Marian R., Jefferson E. Holcomb, and Tomislav V. Kovandzic. 2010. Policing for Profit: The Abuse of Civil Asset Forfeiture. Institute for Justice, pp. 6-120; http://www.ij.org/images/ pdf_folder/other_pubs/assetforfeituretoemail.pdf. 